\title{
The Central Crystallines Around Hapoli, Subansiri, Eastern Himalayas
}

\author{
An Yin ${ }^{1}$, C S Dubey ${ }^{2}$, A A G Webba ${ }^{1}$, P K Verma ${ }^{2}$, T K Kelty ${ }^{3}$ and T M Harrison ${ }^{1}$ \\ 1 Department of Earth and Space Sciences and Institute of Geophysics and Planetary Physics, University of California, Los Angeles, 90095-1567, CA \\ 2 Department of Geology, University of Delhi, Delhi-110007, INDIA \\ 3 Department of Geological Sciences, California State University, Long Beach, 90840-3902, CA
}

Despite a long research history, our understanding of the Himalayan tectonic evolution remain incomplete that can be attributed largely to the lack of geologic constraints on the structural style and timing of deformation in the eastern Himalaya. To overcome this problem, we conducted geologic investigation along traverse from Kimin to Geevan in the District of Upper Subansiri. Prior to our study, researchers had debated on the location of the Main Central Thrust (MCT) across the traverse, with the fault either being placed near the crest line of the Himalayan Range north of latitude $28^{\circ} \mathrm{N}$ or a broadly folded thrust with its frontal trace exposed south of latitude of $27^{\circ} \mathrm{N}$. The above confusion may be attributed to the fact that orthogneiss units, widely exposed in the area, exhibit similar lithology and structural fabrics and are difficult to be determined if they lie in the hanging wall or footwall of the MCT. We address this problem by conducting detailed structural observations and systematic $\mathrm{U}-\mathrm{Pb}$ zircon dating of the orthogneiss units and leucogranits that intrude them. Our mapping reveals that the MCT hanging wall is composed of schist, garnet-biotite gneiss, quartzo-feldspathic gneiss, mylonitic augen gneiss and foliated biotite granitoid. All of the above units are closely associated with Tertiary leucogranites. The MCT is a folded structure expressed as a large half window opening to the west and a small klippe that lies within the half window. The north-south width of the MCT half window requires $>60-\mathrm{km}$ southward slip on the MCT. The MCT hanging wall consists of a prominent ductile thrust shear zone with a thickness $>200 \mathrm{~m}$ at the northern end of our traverse near Geevan. It correlates along strike with the Zimithang shear zone in Tawang and the Kakhtang thrust zone in northern Bhutan. This correlation requires a $>300-$ $\mathrm{km}$ east-west length of the Zimithang-Kakhtang thrust zone in the eastern Himalaya and implies significant amount of crustal shortening within the MCT hanging wall.

We analyzed six orthogneiss samples from the KiminGeevan traverse using the ion microprobe mass spectrometer at UCLA. Sample 1 is from an orthogneiss unit in the MCT hanging wall near Hapoli. We obtained 17 spot analyses on 15 zircons, of which fifteen yield ${ }^{207} \mathrm{~Pb} / 206 \mathrm{~Pb}$ ages ranging from 460.5 Ma to $546.1 \mathrm{Ma}$ with a weighted mean age of $504.9 \pm 8.3 \mathrm{Ma}$. These fifteen analyses are concordant or reversely discordant on the $\mathrm{U}-\mathrm{Pb}$ concordia plot; the increased reverse discordance is associated with higher $\mathrm{U}$ concentrations. The other two analyses yield ${ }^{207} \mathrm{~Pb} /{ }^{206} \mathrm{~Pb}$ ages of $836.9 \pm 13.2 \mathrm{Ma}$ and $730.2 \pm 13.1 \mathrm{Ma}$ and plot along the concordia. Th/ $\mathrm{U}$ ratios of all of the above analyses are $>0.01$, with more than half of them over 0.1 . The grain that yields $826-\mathrm{Ma}$ age is subhedral and its cathodoluminescence image shows distinct domains without clear definition of the core from the rim. A spot yielding the $836.9 \pm 13.2 \mathrm{Ma}{ }^{207} \mathrm{~Pb} /{ }^{206} \mathrm{~Pb}$ age corresponds to a high $\mathrm{Th} / \mathrm{U}$ ratio of 0.419 and is typical of igneous origin. Another spot analysis from the same grain yields a reversely discordant result with a $505.8 \pm 8.3 \mathrm{Ma}{ }^{207} \mathrm{~Pb} /{ }^{206} \mathrm{~Pb}$ age; it corresponds to a low $\mathrm{Th} / \mathrm{U}$ ratio of 0.034 and a $\mathrm{UO} / \mathrm{U}$ ratio below the range of the calibration. The dominant age population of the fifteen out of seventeen analyses and moderate-to-high $\mathrm{Th} / \mathrm{U}$ ratios all indicate the crystallization age of the augen gneiss at $\sim 505 \mathrm{Ma}$ with one inherited grain at $836 \mathrm{Ma}$. As a $825-\mathrm{Ma}$ plutons exist in the Bhutan Himalaya and a 878-Ma augen gneiss is present in the Bhalukpong-Zimithang traverse, the 836Ma zircon may have come from a pluton emplaced during the same igneous event. This interpretation implies that the eastern Himalayan region experienced a magmatic event during 825-878 Ma. Sample 2 was collected from a mylonitic augen gneiss unit in the MCT hanging wall. Of the 15 total analyses from 15 zircons, 13 yield ${ }^{207} \mathrm{~Pb} /{ }^{206} \mathrm{~Pb}$ ages ranging from $1703 \mathrm{Ma}$ to $1780 \mathrm{Ma}$, with a weighted mean age of $1752 \pm 12 \mathrm{Ma}$. Of these 13 analyses, the one with the lowest $\mathrm{Th} / \mathrm{U}$ ratio (0.038) is strongly discordant, plotting along a discordia line with a projected intersection of a Phanerozoic age along the concordia curve. The remaining two analyses have ${ }^{207} \mathrm{~Pb} /{ }^{206} \mathrm{~Pb}$ ages of $1921 \pm 13 \mathrm{Ma}$ and $2515 \pm 12$ $\mathrm{Ma}$; while the younger analysis is nearly concordant, the older one is strongly discordant. We consider these analyses to represent older, wall rock zircons assimilated during emplacement of the granitoid at $\sim 1752 \mathrm{Ma}$. The discordant, low Th/U analysis hints a Phanerozoic metamorphic event. Sample 3 was collected from an augen gneiss unit directly above the MCT. We analyzed six spots of different zircons from sample that yield a discordia line with intercepts on the concordia at $28 \pm 13 \mathrm{Ma}$ and $512 \pm 14 \mathrm{Ma}$ (MSWD $=1.3$ ). Four spot ages cluster near the upper intercept, one plot near the lower intercept with a low $\mathrm{Th} / \mathrm{U}$ value, and one plot between the two age groups. We interpret these results to indicate crystallization of the augen gneiss at $\sim 512$ Ma succeeded by a thermal event at $\sim 28 \mathrm{Ma}$. Sample 4 was from mylonitic augen gneiss in the MCT footwall. We acquired five spot analyses from different zircons. Three analyses cluster together along the concordia, yielding a weighted mean ${ }^{207} \mathrm{~Pb} /{ }^{206} \mathrm{~Pb}$ age of $1747 \pm 7$ Ma. The other two ages are discordant, potentially drawn down from $\sim 1750$ Ma towards the Phanerozoic portion of the concordia. We interpret these results to indicate crystallization of the granitic protolith at $\sim 1747 \mathrm{Ma}$ and a later Late Proterozoic or Phanerozoic $\mathrm{Pb}-$ loss event that may correlate with metamorphism. Sample 5 was collected from a biotite-quartz mylonitic granitoid that lies directly above the MCT Geevan klippe. We analyzed five spots of different zircons and four of them clustering on the concordia yield 
a weighted mean ${ }^{207} \mathrm{~Pb} /{ }^{206} \mathrm{~Pb}$ age of $1743 \pm 7 \mathrm{Ma}$. One spot age is slightly older with a ${ }^{207} \mathrm{~Pb} /{ }^{206} \mathrm{~Pb}$ age of $1939 \pm 9 \mathrm{Ma}$. We interpret these results to indicate crystallization of the granitic protolith at $\sim 1743 \mathrm{Ma}$, with the single older age representing an inherited component. Sample 6 was from an augen gneiss directly above the MCT and north of sample 5. We acquired four spot analyses from different zircons. Three analyses cluster on the concordia indicating a weighted mean ${ }^{207} \mathrm{~Pb} /{ }^{206} \mathrm{~Pb}$ age of $1772 \pm 6 \mathrm{Ma}(2 \bullet)$ (Figure 1). We interpret these results to indicate crystallization of the granitic protolith at $\sim 1772 \mathrm{Ma}$.

In addition to dating the orthogneiss, we also obtained U$\mathrm{Pb}$ ages from leucogranites in our study area. The first sample was from a leucogranite that intrudes a 1752-Ma augen gneiss in the MCT hanging wall. Of the fourteen zircon analyses we obtained, six are discordant, four have $\mathrm{UO} / \mathrm{U}$ values exceeding the range of calibration, and another four have $\mathrm{Th} / \mathrm{U}$ values below 0.1 . The data plot along a discordia line that intercepts the concordia curve at $373 \pm 59 \mathrm{Ma}$ below and $1759 \pm 36 \mathrm{Ma}$ above $(\mathrm{MSWD}=1.4)$. The upper intercept age overlaps with the crystallization age of the host rock at $1752 \pm 12 \mathrm{Ma}$ and likely reflects inheritance of wall-rock zircons. The wall-rock zircons may have experienced Phanerozoic metamorphism during zircon growth as indicated by moderate to low $\mathrm{Th} / \mathrm{U}$ values. Considering the large uncertainty for this age, it is likely that the metamorphic event was related to the widespread Cambro-Ordovician plutonism and metamorphism across the Himalaya. Thus, the above interpretation suggests that some Himalayan leucogranite may have emplaced in the early Paleozoic as well. Our second leucogranite sample was from a vein that intrudes a 500-Ma granitoid in the MCT hanging wall. Five analyses plotted in two concordant clusters, three of which yield a ${ }^{207} \mathrm{~Pb} /{ }^{206} \mathrm{~Pb}$ weighted mean age of $491 \pm 11 \mathrm{Ma}$ $(2 \bullet)$ and the other two featuring very low $\mathrm{Th} / \mathrm{U}$ ratios yielding ${ }^{238} \mathrm{U} /{ }^{06} \mathrm{~Pb}$ weighted mean ages of $24.6 \pm 0.5 \mathrm{Ma}$ and $24.4 \pm 0.3$ Ma. Additional two spot analyses plotted along a discordia line between the two age clusters. The $\sim 491 \mathrm{Ma}$ age zircons may represent inherited zircons from the wall rocks and the younger zircons may result from crystallization of the leucogranite at $\sim 24$ Ma. Our last sample was from a leucogranite intruding highgrade gneiss in the MCT hanging wall. We analyzed nine spots on different zircons (Figure 2). One analysis with a high $\mathrm{Th} / \mathrm{U}$ ratio yields a ${ }^{207} \mathrm{~Pb} /{ }^{206} \mathrm{~Pb}$ weighted mean age of $1746 \pm 14 \mathrm{Ma}(2 \bullet)$; the rest yield moderate to low $\mathrm{Th} / \mathrm{U}$ ratios and Cenozoic ${ }^{238} \mathrm{U} / 206 \mathrm{~Pb}$ ages, with a dominant age cluster from $\sim 23.5 \mathrm{Ma}$ to $\sim 20 \mathrm{Ma}$. We interpret the $\sim 1746 \mathrm{Ma}$ age as reflecting inheritance from the wall rocks and the younger ages indicate crystallization of the leucogranite at 23-20 Ma.

In order to understand the evolution of the Himalaya along the Kimin-Geevan traverse, we constructed a balanced cross section and performed a systematic restoration of the section. Our structural analysis leads to an estimate of $190-\mathrm{km}$ shortening and a corresponding horizontal shortening strain of $76 \%$. As the region may have experienced significant Cambro-Ordovician deformation as indicated by the wide occurrence of 480-500 Ma granitoids, the above shortening estimate should be regarded as a combined effect of early Paleozoic and Cenozoic deformation, thus only placing an upper bound for the actual shortening strain in the Cenozoic.
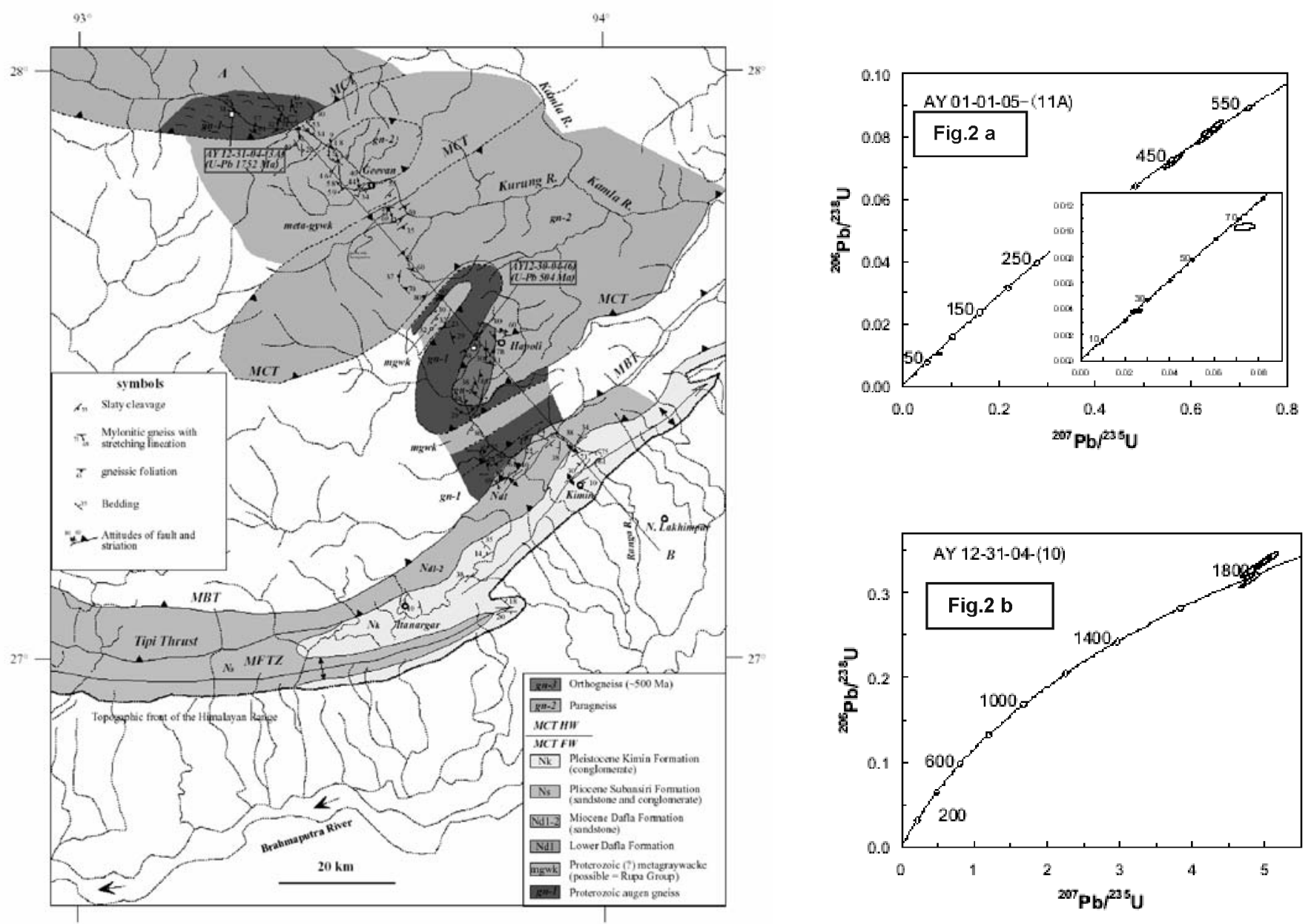

HIMALAYAN JOURNAL OF SCIENCES | VOL. 5 | ISSUE 7 (SPECIAL ISSUE) | 2008 